University of Nebraska - Lincoln

DigitalCommons@University of Nebraska - Lincoln

March 1988

\title{
DETERMINATION OF THE ENVIRONMENTAL FATE OF GROUND SQUIRREL CARCASSES
}

Daniel Sullivan

Montana Department of Agriculture, Capitol Station, Helena, Montana

Follow this and additional works at: https://digitalcommons.unl.edu/vpcthirteen

Part of the Environmental Health and Protection Commons

Sullivan, Daniel, "DETERMINATION OF THE ENVIRONMENTAL FATE OF GROUND SQUIRREL CARCASSES" (1988). Proceedings of the Thirteenth Vertebrate Pest Conference (1988). 35.

https://digitalcommons.unl.edu/vpcthirteen/35

This Article is brought to you for free and open access by the Vertebrate Pest Conference Proceedings collection at DigitalCommons@University of Nebraska - Lincoln. It has been accepted for inclusion in Proceedings of the Thirteenth Vertebrate Pest Conference (1988) by an authorized administrator of DigitalCommons@University of Nebraska - Lincoln. 


\title{
DETERMINATION OF THE ENVIRONMENTAL FATE OF GROUND SQUIRREL CARCASSES
}

DANIEL SULLIVAN, Montana Department of Agriculture, Capitol Station, Helena, Montana 59620-0205.

\begin{abstract}
A field study was conducted in Lewis and Clark County, Montana, during the summer of 1986 to determine the fate of Columbian ground squirrel (Spermophilus columbianus) carcasses in the environment. Ground squirrel carcasses were marked with radio transmitters and placed in situations and locations similar to those found in actual rodent control operations. Carcasses were monitored until their fate was determined or until they were no longer considered attractive to scavengers. Red fox (Vulpes fulva) was the primary scavenger in this study. Striped skunk (Mephitis mephitis) and birds (corvids and/or raptors) were the other mammalian and avian scavengers identified. Carrion-eating insects quickly attacked the carcasses and were important in determining the maximum exposure time of the carcasses to scavengers. Factors determining the risks to scavengers from rodent control operations and management techniques to reduce nontarget hazards are discussed.
\end{abstract}

Proc. Vertebr. Pest Conf. (A.C. Crabb and R.E. Marsh, Eds.),

Printed at Univ. of Calif., Davis. 13:169-173, 1988

\section{INTRODUCTION}

Field rodents, such as ground squirrels that damage agricultural crops, are often controlled using various rodenticide baits (Record 1978, Salmon and Schmidt 1984, Sullivan 1986). After rodenticide treatment, field rodent carcasses may be found on the ground surface in the treatment area (Matschkeetal. 1982,Hegdaletal. 1986). Because the carcasses may contain some quantity of the rodenticide, which may be hazardous to animals scavenging on them (Mendenhall and Pank 1980, Hegdal et al. 1981, Kaukeinen 1982), the fate and degradation time of the carcasses in the environment is of interest. Field studies have been conducted to assess the hazard of ground squirrels killed by rodenticides to scavengers and predators (Hegdal et al. 1986) but no previous field study has attempted to monitor individual carcasses and determine their fate.

\section{STUDY OBJECTIVE}

The study objective was to determine the fate and degradation time of ground squirrel carcasses in the environment. This was accomplished by placing marked ground squirrel carcasses in study areas in a manner that simulated the carcass density and location found following a normal rodent control program. The carcasses were monitored until their fate was determined or they decomposed to a point where they were no longer believed to be attractive to scavengers.

\section{METHODS}

Study Area

Two study sites were selected in Lewis and Clark County, Montana. Each site was occupied by Columbian ground squirrels (Spermophilus columbianus) and represented areas where rodent control is a usual practice. Both study areas were dryland pastures and noncrop areas bordering crops of alfalfa and small grain. The study areas were 3 $\mathrm{km}$ apart. The general area surrounding the study sites is agricultural land although a suburban subdivision, an industrial park and an airport are within a $5 \mathrm{~km}$ radius of the study areas. The major agricultural crops in the area are alfalfa hay, pastures and small grains. The main canal of the area irrigation system passes next to both study sites. A stream bordered by deciduous trees and shrubs runs within $3 \mathrm{~km}$ of each site.

\section{$\underline{\text { Squirrel Capture }}$}

Columbian ground squirrels were live-trapped from nearby fields and killed using $\mathrm{CO}_{2}$ gas. After death, squirrel carcasses were handled using surgical gloves and stored individually in polyethylene bags to minimize contamination by foreign odors. Each squirrel was weighed, sexed and toeclipped for individual identification. Squirrel carcasses placed in the field within one or two days after death were stored under refrigeration. Squirrel carcasses held for a longer period of time were frozen. Frozen carcasses were thawed under refrigeration before they were placed in the field.

\section{Radio Telemetry}

Each carcass was fitted with a radio transmitter set to a different frequency allowing identification of individual squirrel carcasses. In addition to a standard collar attachment, the transmitter collars were secured to the skeleton by passing a nylon tie through the carcass around the pectoral girdle.

Transmitters were inexpensively constructed (US \$7 each) and transmitted in the $27.965-27.405 \mathrm{MHz}$ frequency range (Modified from Morris 1979). A tuned loop antenna constructed of copper tubing comprised the collar. A $10 \mathrm{~cm}$ whip antenna was attached to the tuned loop. Above ground transmitter range was 1.5 to $2.0 \mathrm{~km}$. Hand-held 40 channel Citizens Band receivers with external dipole antennas were used for signal reception and location. 


\section{Carcass Placement}

Ground squirrel carcasses were placed on each study site at a density of approximately ten carcasses per hectare in active squirrel colonies. This density is the maximum carcass density observed by Sullivan (1982) using bait stations containing anticoagulants in similar situations. Five carcasses per day were placed on each study site for four consecutive days for a total of twenty carcasses per site.

Equal numbers of carcasses were placed in each of four situations. These situations were based on locations of squirrel carcasses found after actual rodent control operations (Sullivan 1982). These locations were designated in the following manner: LI: Burrow Opening - 0\% cover; L2: 0 25\% cover; $\mathrm{L} 3: 25 \%-50 \%$ cover; $\mathrm{L} 4:>50 \%$ cover.

\section{Monitoring}

Carcasses were monitored once per day. Observations continued until the carcasses were consumed by scavengers or were completely degraded by insects.

When possible, avian and mammalian scavengers were identified from field sign (tracks, scat), carcass remains that indicated feeding behavior typical of certain scavengers, association of carcasses or transmitters with den areas, and knowledge and observation of potential scavengers in the area. Carrion-eating insects found on the carcasses were collected and identified.

Weather information, including daily minimum and maximum temperatures and daily precipitation, was recorded during the study period.

Control carcasses, caged and fenced to prevent access by avian and mammalian scavengers while allowing access by insects, were used to determine carcass degradation times when not disturbed by larger scavengers. Carcass weight and condition were recorded daily. Carcasses were observed for nine days.

This study was conducted on one site during the first two weeks of June, 1986 following emergence of the young-ofthe-year from their natal burrows. It was repeated on the second site during the first two weeks of August, 1986 before estivation by the squirrels. Control programs for the Columbian ground squirrel are often conducted during both periods in Montana.

\section{RESULTS}

Fox (Vulpes fulva) were the major scavengers identified in this study and are believed to have consumed at least 14 carcasses. Unknown scavengers consumed 11 carcasses. Field observations indicated that fox and skunk (Mephitis $\underline{\text { mephitis) }}$ were the most likely scavengers involved. Four carcasses were scavenged by birds (corvids or raptors). Carrion-eating insects were responsible for the degradation of eight carcasses and had begun degradation of most of the other carcasses prior to consumption by avian or mammalian predators. The transmitter signals from three carcasses were not received when the carcasses were initially moved and their fate is unknown (Table 1).
Table 1. Placement location, carcass longevity and carcass fate.

\begin{tabular}{|c|c|c|c|c|c|c|}
\hline \multirow{2}{*}{$\begin{array}{l}\text { Car- } \\
\text { cass } \\
\text { No. }\end{array}$} & \multicolumn{3}{|c|}{ Site 1 (June) } & \multicolumn{3}{|c|}{ Sile 2 (August) } \\
\hline & Lui & Days* & * Fate Lo & & Days" & Fate \\
\hline 1 & L4 & 3 & Unk(tux/skunk?) & $\mathrm{Ll}$ & 1 & Unkiskunk?') \\
\hline 2 & L3 & 3 & $\begin{array}{l}\text { Unk(ftrx/skunk?) } \\
\text { found in burrow }\end{array}$ & L3 & 6 & $\ln \sec t$ \\
\hline 3 & Li & 4 & Uak(foxiskunk?) & $\mathrm{L} 2$ & 7 & Insite: \\
\hline 4 & $\mathrm{~L} 2$ & 1 & Fox(iten area) & 14 & 5 & Unkịskank"?) \\
\hline 5 & LI & 8 & Insect & J.I & 6 & Insoct \\
\hline 6 & L2 & 2 & Fox (den area) & L2 & 5 & Fox(den area) \\
\hline 7 & L4 & 4 & Fox(den area) & L3 & 2 & Unk(skunk?) \\
\hline 8 & $\mathrm{I} A$ & 4 & $\mathrm{I}, 0 \mathrm{st}$ & LI & 1 & Lost \\
\hline 9 & I.1 & 2 & I.061 & L4 & 5 & Foxiden area) \\
\hline 10 & $\mathrm{~T} .3$ & 3 & Fos(den arca) & L2 & 4 & Foxiden area) \\
\hline 11 & $\mathrm{~L} 2$ & 1 & Unk(fox/skunk? $)$ & $\mathrm{L3}$ & 3 & Fox (uten arca) \\
\hline 12 & L1 & 2 & Fox(den area) & L4 & 3 & Lnk(skunk?) \\
\hline 13 & $\mathrm{~L} 2$ & 2 & Fox(den area) & L1 & 2 & Unk(skmk?) \\
\hline 14 & $\mathrm{Ll}$ & 5 & Fox(den uresi) & L3 & 2 & Unkaskumk?)"** \\
\hline 15 & LA & 3 & Fox(den area) & $\mathrm{L4}$ & 2 & Birck \\
\hline 16 & $\mathrm{LA}$ & 3 & Foxiden area) & 1.1 & 4 & Binds \\
\hline 17 & I. 3 & 4 & Biuds & 1.2 & 5 & Insece \\
\hline 18 & $\mathrm{~L} 2$ & 6 & Biruls & L4 & 5 & Insert \\
\hline 19 & 1.3 & 2 & Lnk (foxiskunk?) & $1 / 4$ & 5 & Insect \\
\hline \multirow[t]{2}{*}{20} & L3 & 4 & lüux & $\mathrm{L2}$ & 5 & Insext \\
\hline & & $3.05 \mathrm{~A}$ & Ave. ${ }^{4 * 2}$ & & 3.00 & Ave. ${ }^{-\cdots}$ \\
\hline
\end{tabular}

*Loc: Carcass Placement Location. LI-burrow opening; L2 - 0-25\% cover; L3 - 25-50\% cover; L4 - >50\% cover

**Days: Carcass Longevity post placement on study site.

*** Found in burrow.

****Ave: Average carcass longevity for carcasses other than those degraded only by insects. 
Carcass longevity after placement on the study sites ranged from one to eight days. The average longevity, excluding carcasses degraded by insects alone, was three days (Table 1). The number of carcasses taken by scavengers or degraded by insects for each successive day after placement is shown in Table 2.

Table 3 shows the longevity of carcasses by placement location. The data indicate that there is little or no relationship between carcass longevity and the visibility of the carcasses.

Table 2. Carcass longevity by day, post placement.

\begin{tabular}{lccc}
\hline $\begin{array}{l}\text { Carcass } \\
\text { Longevity } \\
\text { In Days }\end{array}$ & $\begin{array}{c}\text { No. of } \\
\text { Carcasses }\end{array}$ & $\begin{array}{c}\text { No. of } \\
\text { Carcasses }\end{array}$ & $\begin{array}{c}\text { No. of } \\
\text { Carcasses }\end{array}$ \\
\hline \hline 1 & $2(10 \%)$ & $2(10 \%)$ & $4(10 \%)$ \\
2 & $5(25 \%)$ & $4(2(6 \%)$ & $9(22.5 \%)$ \\
3 & $5(2.5 \%)$ & $2(10 \%)$ & $7(17.5 \%)$ \\
4 & $5(25 \%)$ & $2(10 \%)$ & $7(17.5 \%)$ \\
5 & $1(5 \%)$ & $6(30 \%)$ & $7(17.5 \%)$ \\
$>5$ & $2(10 \%)$ & $4(20 \%)$ & $6(15 \%)$ \\
\hline
\end{tabular}

Table 3, Carcass longevily by placement location.

\begin{tabular}{|c|c|c|c|c|c|c|c|c|c|c|c|c|}
\hline & \multicolumn{6}{|c|}{ Site 1} & \multicolumn{6}{|c|}{ Sita 2} \\
\hline & & & ays & & & Ave. & & Dily & & & & Ave \\
\hline $\begin{array}{l}\text { L.1 } \\
\text { Burrow } \\
\text { Openin! }\end{array}$ & 4 & (8) & 2 & 2 & 5 & 4.20 & 1 & (6) & $t$ & & 4 & 2.33 \\
\hline $\begin{array}{l}\text { L2 } \\
0-25 \% \\
\text { Cover }\end{array}$ & 1 & 2 & 1 & 2 & 6 & 2.40 & (7) & 5 & 4 & & (5) & 5.20 \\
\hline $\begin{array}{l}1.3 \\
2.5-5 \mathrm{ks} \\
\text { Cover }\end{array}$ & 3 & 3 & 4 & 1 & 4 & 3.20 & (6) & 2 & 3 & 3 & (7) & $4,(n)$ \\
\hline $\begin{array}{l}\mathrm{L} 4 \\
>5 \mathrm{HW} \\
\text { Cover }\end{array}$ & 3 & 4 & 4 & .3 & 3 & 3,40 & $(5)$ & 5 & 3 & 2 & (5) & $4,(\mathrm{X})$ \\
\hline
\end{tabular}

Carrion-eating insects determined the maximum degradation time if carcasses were undisturbed by larger scavengers (Table 1). Flies found the carcasses within the first day of placement on the study sites. It was not unusual to observe flies on and around the carcass immediately after the carcass was placed on the ground. Fly egg masses were found on most carcasses by the end of two days. By Day 4, carcass weight decreased by an average of 24 percent and fly larvae represented 25-50 percent of the total carcass weight. At Day 6 most of the viscera and muscle tissue had been consumed by the fly larvae. The carcass was largely a shell of skin and bone providing shelter for the larvae. By Day 7 most fly larvae had disappeared from the carcass. The remaining carcass, sometimes appearing little changed from its original appearance, continued to desiccate to $10-15$ percent of its starting weight (Table 4, Figure 1). Various species of beetles and ants were also attracted to the carcasses but probably contributed only slightly to carcass degradation. The carrion-eating insects observed in this study included Blow flies (Calliphoridae), Flesh flies (Sarcophagidae), Carrion beetles (Silphidae), Rove beetles (Staphylinidae), Dung beetles (Scarabaeidae), and Harvester ants (Formicidae).

During the June study period minimum and maximum temperatures were $10^{\circ} \mathrm{C}$ and $27.5^{\circ} \mathrm{C}$, respectively and $1.8 \mathrm{~mm}$ of precipitation was recorded. Minimum and maximum temperatures during August were $9.5^{\circ} \mathrm{C}$ and $30.5^{\circ} \mathrm{C}$, respectively. Only a trace of precipitation was recorded.

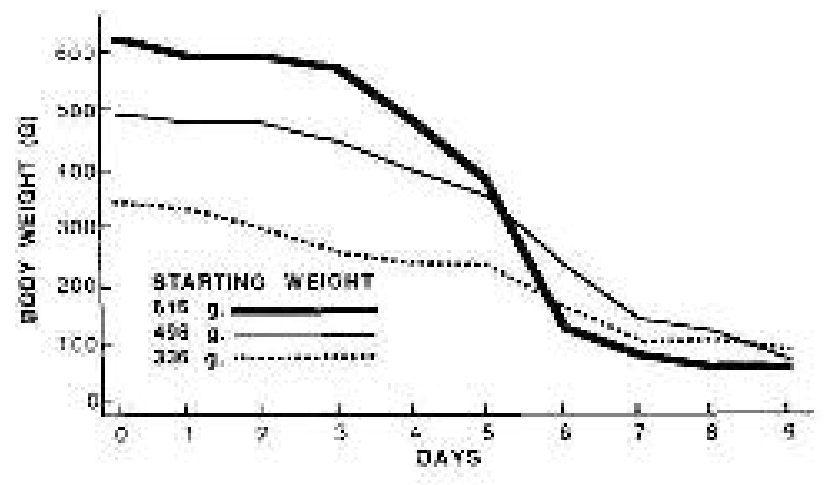

Fig. 1. Daily weight loss of ground squirrel carcasses caged from scavengers but allowing access by insect fauna.

\section{DISCUSSION}

The fate of carcasses is dependent on the scavenger fauna present at the site where rodent control is conducted. The species present and the relative proportions of each will be different at each site depending on the habitat and geographic location. In this study terrestrial predators (fox and skunk) were the dominant scavengers. In areas where these animals are not common or are not present, the fate of carcasses can be expected to be different. 
Table 4. Generalized degradation of ground squirrel carcasses by carrion-eating insects.

Days Post
Carcass Ave $\%$
Placement Weight Loss Carcass Condition

$0 \quad 0 \quad$ Flies present on and around carcass.

$1 \quad 3.7 \quad$ Carcass not noticeably changed. Flies present. Usually oo obvious egg masess.

26.1 T.tule change in overall uppearance, cyes may be sunken and abdomen bloated. Slight oflor may be present. Fly egr masses present. Occasionally small hy larvac are found. Ants and beetles present.

313.0 Carcass cxkur obvicus. Flies abundant, increasing number and variety of hectles. Numerous fly egg masits and small larvac.

24.0 Strong odor, Eycs and abdomen sunken. Hait may begin slesughing from some carcasses. Fly larvae throughtoul viscera and moving into muscle tixsuc. Fly larvae represent $25-50 \%$ of carcass weight. Numerous beetles. Ants feting on larvox

34.4 Similar to Day 4 but thy larvac represent the majcrity of body weight and are found throughout the muscle tissue. still be present but carcass is usually a shell of drying skin and bones.

77.6 Most larvac are gnnc atthough portions of carcass may still be occupicd (cosum, skall \& neck)

Beetlesiants present. it few adult flics are scen.

81.0 Carcass continues to desiccate.
Carrion-eating insects are very important for carcass degradation. They determine the maximum exposure time of carcasses to scavengers. In this study the maximum exposure time was about one week. Because of the flies' ability to locate and consume the carcass so rapidly and the likely metabolism and degradation of rodenticide residues by action of the larvae, the first three or four days of exposure present the greatest risk to scavengers. Rodenticide residues may affect carcass degradation by carrion-eating insects. However, personal observations of carcasses found after rodent control programs indicate that carrion-eating insects effectively attack ground squirrels killed by strychnine, 1080 and various anticoagulant rodenticides.

The degree of risk to nontarget scavengers in an actual rodent control program is dependent on several factors:

1. Availability of carcasses (i.e., the number of animals dying above ground).

2. The rodenticide used (relative toxicity, acute vs multidose).

3. The ability of the target rodent to detoxify the rodenticide before death.

4. Rate and method of rodenticide applications which determine the carcass residue load.

5. Sensitivity of each nontarget species to the rodenti cide used.

6. The ability of the scavenger to locate carcasses, particularly immediately after death.

7. The rate of rodenticide degradation in the carcass.

8. Carcass longevity.

Rodenticide users must be fully aware of these risk factors, which are different for each rodenticide, to assess and reduce risks to nontarget species.

Current rodent control methods and materials available to agricultural producers involve a certain risk of nontarget death. Clearly, the foxes scavenging on squirrel carcasses in this study would have been at risk if the carcasses had contained residues of some of the commonly used rodenticides. This study indicates that management of depredating rodent populations is not limited to prevention of rodent damage by use of rodenticides or other methods, but also concerns management of risks to nontarget populations.

Methods and techniques available to reduce hazards to nontarget animals include: 1) Proper selection of rodenticides with the least hazard to the known nontarget species on the treatment area, 2) Selection of toxicant bait concentrations that are not greater than necessary for optimum efficacy, and 3) Bait application at rates and with methods that limit overconsumption of bait by the target rodents (Marsh 1985). Management after bait application can further reduce nontarget risks. This may include placement of warning signs and notification of neighboring landowners to encourage confinement of pets and livestock, disposal of surface-killed rodent carcasses and actions that discourage use of the treatment area by nontarget species.

Farmers and ranchers need to control rodent populations that damage agricultural crops. Because rodenticides are both effective and economical, they will remain the primary 
control method in the foreseeable future, especially on larger crop acreages. The question is not whether nontarget mortality will occur with current rodent control technology, but whether risks to nontarget populations can be managed. A distinction must be made between the effect on a few individual nontarget animals, excluding species classified as threatened or endangered, and effects on nontarget populations. With full knowledge of the nontarget risk factors and implementation of sound rodent management practices and precautions for nontarget safety, impact to nontarget populations can be kept within acceptable limits.

\section{ACKNOWLEDGMENTS}

Financial support was provided by the Chempar Products Division of Lipha Chemicals, Milwaukee, Wisconsin, and the Montana Department of Agriculture. Dan Pond designed and constructed the transmitters and provided valuable assistance in the field. Bob Gillespie identified the insect fauna. The manuscript was reviewed by George Algard, Monty Sullins, John Larson and Lynne Alexander. I am grateful to landowners Dave Baum and Donald Burnham for permitting access to their properties to conduct the study.

\section{LITERATURE CITED}

HEGDAL, P.L., K.A. FAGERSTONE, T.A. GATZ, J.F. GLAHN, and G.H. MATSCHKE. 1986. Hazard to wildlife associated with 1080 baiting for California ground squirrels. Wildl. Soc. Bull. 14:11-21.

HEGDAL, P.L., T.A. GATZ, and E. C. FITE. 1981. Secondary effects of rodenticides on mammalian predators. Proc. Worldwide Furbearer Conf. 1:1781-1793.

KAUKEINEN, D. 1982. A review of the secondary poison- ing hazard to wildlife from the use of anticoagulant rodenticides. Proc. 10th Vert. Pest Conf., Monterey, California, pp 151-158.

MATSCHKE, G.H., K.A. FAGERSTONE, N.D. HALSTEAD, G.K. LAVOIE and D.L. OTIS. 1982. Population reduction of Richardson's ground squirrels with zinc phosphide. J. Wildl. Manage. 46(3):671-677.

MARSH, R.E. 1985. Techniques used in rodent control to safeguard nontarget wildlife, pp. 47-55 In: Trans. West. Sect. Wildl. Soc, W.F. Laudenslayer (ed.), Monterey, California.

MENDENHALL, V.M. and L.F. PANK. 1980. Secondary poisoning of owls by anticoagulant rodenticides. Wildl. Soc. Bull. 8:311-315.

MORRIS, P. 1979. An elementary guide to practical aspects of radio tracking mammals, pp. 161-168 In: A handbook of biotelemetry and radio tracking, C.J. Amlaner and D.W. MacDonald (eds.), Pergamon Press.

RECORD, C.R. 1978. Ground squirrel and prairie dog control in Montana. Proc. 8th Vert. Pest Conf., Sacramento, California, pp. 93-97.

SALMON, T.P. and R.H. SCHMIDT. 1984. An introductory overview of California ground squirrel control. Proc. 1 1th Vert. Pest Conf., Sacramento, California, pp. 32-37.

SULLIVAN, D. 1986. Chemicals registered for vertebrate pest control in Montana. Montana Dept. of Agriculture Publ., Capitol Station, Helena, Montana. 45 pp.

SULLIVAN, D. 1982. Bait stations as a means of rodenticide presentation to control Columbian ground squirrels. Montana Department of Agriculture, Capitol Station, Helena, Montana. Technical Report 82-3. 26 pp. 
